\title{
Occurrences, Distribution and Composition of Microplastics in the Surface Seawater and Beach Sediments of the Southern Shandong Peninsula, China
}

\author{
Rashid Pervez ( $\square$ rashid.pervez@hotmail.com ) \\ Shantou University \\ Yonghong Wang \\ Ocean University of China \\ Zhongpeng Lai \\ Shantou University
}

\section{Research Article}

Keywords: Microplastics, Shandong, Microscopy, Fourier Transform Infrared Spectroscopy, Sediment, Beach

Posted Date: August 24th, 2021

DOI: https://doi.org/10.21203/rs.3.rs-790759/v1

License: (c) (1) This work is licensed under a Creative Commons Attribution 4.0 International License.

Read Full License 


\section{Occurrences, distribution and composition of microplastics in the surface seawater and beach sediments of the southern Shandong Peninsula, China}

\section{Rashid Pervez $^{\mathrm{a}, \mathrm{b}, \mathrm{c}}$, Yonghong Wang ${ }^{\mathrm{b}, \mathrm{c}}$ Zhongpeng Lai $^{\mathrm{a}}$}

${ }^{a}$ Institute of Marine Sciences, Guangdong Provincial Key Laboratory of Marine Biotechnology, Shantou University, Shantou 515063, China

${ }^{b}$ Key Lab of Submarine Geosciences and Prospecting Techniques, MOE, College of Marine Geosciences, Ocean University of China, Qingdao 266100, PR China.

'Laboratory of Marine Geology and Environment, Qingdao National Laboratory for Marine Science and Technology, Qingdao 266237, China. 


\section{Abstract}

2 The current work provides the detailed analysis about microplastics contamination of the beach sediments and 3 surface seawater. Sediment samples were collected from the high tidal zone at 13 beaches, and surface seawaters 4 of seven stations along the southern Shandong Peninsula. The presence of microplastics was recorded on both 5 beaches and surface seawater. The mean quantity of microplastics was approximately $664 \pm 80$ microplastics $/ \mathrm{kg}$ 6 of dry weight (dw) with $0.5 \sim 0.125 \mathrm{~mm}$ in beach sediments, and $5.62 \pm 0.4$ microplastics/liter (L) of surface 7 seawater. Predominant microplastics were fibers (>97\%). While other plastic forms had lower percentage. 8 Microplastics possessed different color with polymer composition including polypropylene, polyethylene, and 9 polystyrene. The accumulation of microplastics on beaches is an alarming issue and provides better understanding about microplastics pollution along the coastal regions of the southern Shandong Peninsula. It would also help to

11 establish better monitoring system for future and evaluate possible risks by microplastics due to rapid economic growth of China.

13 Keywords: Microplastics, Shandong, Microscopy, Fourier Transform Infrared Spectroscopy, Sediment, Beach 
The occurrences and distribution of microplastics $(<5 \mathrm{~mm})$ is an alarming issue and attracted more attention and concerns in recent years (Sarijan et al. 2021). There is no standard criteria to define microplastics but particles with size $5 \mathrm{~mm}$ is generally separate from larger particles (Browne et al. 2010). Microplastics are mainly classified into two types: primary and secondary microplastics. The key sources of primary microplastics are household, commodities and different industrial sectors (Rochman 2015). Secondary microplastics originate from disintegration of larger plastic particles under the influence of solar radiation, temperature, biological and physical damage (Andrady 2017). Microplastics enter into marine and beach environments due to mismanagement of waste material involving marine-related activities such as fishing, recreation, swimming etc (Pereao et al. 2020). Moreover, these particles can persist in aquatic environment for long time before their mineralization after discharge (Law and Thompson 2014). Upon their entry into marine environment, various plastic materials pose threat to marine ecosystem (Anbumani et al. 2018).

Microplastics may be ingested by marine organism such as sea cucumber Stichopus horrhorrens in Pulau Pangkor (Husin et al. 2021), bacterial biofilms communities (Tavsanoglu et al. 2020), gastrointestinal tract of different species (Klangnurak et al. 2020), fish guts (Caruso et al. 2018) including human health (Sana et al. 2020). These microplastics persist in several morphologies namely fibers, spheres, films, microspheres, and fragments (Naidoo et al. 2015), with size varying from nano (n) to millimeter ( $\mathrm{mm}$ ) (Ter Halle et al. 2016). Chemically, microplastics are mainly constituted polystyrene (PS), polypropylene (PP), polyvinylchloride (PVC), polyethylene (PE), polyethylene terephthalate (PET) and few others with varying densities (Engler 2012). Microplastics are transported into ocean thru streams, rivers, storm water, and sewerage system after production at land (Doyen et al. 2019). The transporting agents are tourism, recreational activities, voyages, commercial fishing, coastal tourism, and marine-related industries (oil rigs and aquaculture) are noteworthy causing shift of microplastics to marine environment (Veerasingam et al. 2016).

Microplastics have already been identified throughout the maritime environment, containing beaches (Wu et al. 2020), open ocean (Cózar et al., 2014), remote island (Ivar et al. 2009), river (Mai et al. 2021), and marine sediment (Sharma et al. 2017). The occurrences and distribution of microplastics in beach sediment denotes longterm accumulation which acts as the persistent interfacial contact between seawater and coastal area. It was investigated that sampling from the coastal beaches is an economical and cost-effective approach to determine microplastics (Hidalgo-Ruz and Thiel 2013). When compared to mesoplastics, macroplastics and microplastics cause less visual impact when they are present in the environment; however, these cause physio-chemical imprints in food web (Ajith et al. 2020). Thus, studies about distribution and accumulation of microplastics on beaches are crucial for sustainable coastal and marine environment. A number of studies about distribution and quantification of microplastics have been accomplished on several beaches worldwide (Tiwari et al. 2019). Likewise, Colombian Caribbean (Barletta et al. 2019), Iran (Dehghani et al. 2017), Spanish (Masiá et al. 2019), and India (Gopinath et al. 2020). The transportation and distribution of microplastics on beaches may be affected with different factors such as winds, tides, anthropogenic activities, and water currents (Iwasaki et al. 2017).

A rapid economic growth has been witnessed in China during a recent past; however, about 8.82 million tons of plastic waste has been mismanaged in 192 coastal countries including China (Jambeck et al. 2015), and the awareness on the environmental and waste management was limited (Zhang et al. 2018). The Shandong Peninsula 
is bound by Yellow and Bohai Sea. Numerious studies have been carried out to address microplastics issue in China (Xu et al. 2020; Shen et al. 2021; Wang et al. 2021; Yuan et al. 2021). Recently, we found few studies about the different aspects of microplastics which encompass the Yellow Sea (Sun et al. 2018, 2019; Xiong et al. 2018; Zhou et al. 2018; Zhang et al. 2019; Zhao et al. 2019; Gao et al. 2020). This is essential to assess the level, distribution, and detection of microplastics to understand the level of pollution and enlighten the contributing factors of microplastics in the region. Thus, the sand samples collected from thirteen beach sites and surface seawater samples from seven stations, and identified types, color, shape, and chemical composition. All these beach sites are located in the Shandong Province, comprising intense, highly developed and urbanized coastlines. This information will help to emphasize the gravity of microplastics pollution and highlights the critical region with other factors for an immediate attention. The work offers a better understanding regarding microplastics distribution in the coastal region of the southern Shandong, eventually encompasses better knowledge about how to improve coastal management to protect the marine ecosystems.

\section{Materials and methods}

\section{Study Area}

Shandong is one of the important coastal provinces of China with annual economic growth from marine resources in the range of 7.15 billion dollars $(\$)$ to $\$ 17.2$ during 2013-18. There are famous sandy coastlines including several beaches in the southern Shandong province including Rizhao, Qingdao, and Rongcheng region. These beaches are very popular for fishing, tourism, swimming, recreational, and aqua culture-related activities adjacent to urban area of the southern Shandong Province. Tourism plays a vital role in the economy of these three cities. Especially, Qingdao receives >30 million tourists every year comprising of 88.160000.0 million foreign and domestics tourists in 2017, which were rapidly increasing on yearly basis. Qingdao is a popular tourist spot in China (Liu et al. 2019). A huge flux of beach visitors utilized these beaches for recreational and tourism activities. For example, more than 200,000 beach visitors were reckoned in the summer season on Golden bathing beach, Qingdao ${ }^{1}$. The present study area comprised of thirteen sandy beaches (Error! Reference source not found., E1 E13), and seven surface seawater stations (Error! Reference source not found., W1 - W7), along the southern coastline of Shandong. This area normally experiences coastal monsoons owing to its warm temperate climate and assigned as top second city in China concerning investments and efficient government (Mako 2006). The annual rainfall in this region varies from the range of $400 \mathrm{~mm}$ to $1335 \mathrm{~mm}$, with the mean annual temperature of approximately $12.4^{\circ} \mathrm{C}$.

\section{Sampling of sediments and water}

Overall, thirteen beaches (one from Rongcheng, two from Huangdao, four from Rizhao region, and six from Qingdao region) were selected to acquire microplastics samples (Error! Reference source not found.). The sampling was collected in July 2019 on different dates. The detailed features of each sampling location were enlisted in supplementary information (Table S1). Number of plastics, rainfall and storm were observed during sampling period. Beach sampling techniques were selected based on the pervious standard procedures (Lots et al. 2017; Bosker et al. 2018). For each selected sampling site, a high tide line was identified to mark the boundary of

1 http://news.qingdaonews.com/qingdao/2015-08/17/content_11209692.htm (Chinese translation) 
wet sand, litter, or shell deposited sites. For every beach, five sediment samples were collected around the higher tidal line along the coastline with an interval of $10 \sim 15 \mathrm{~m}$ with five replications for each sample. A $0.25 \mathrm{~m}^{2}$ quadrant was employed for each beach sample. Samples were collected from the top and corner of 5 to $10 \mathrm{~cm}$ quadrant using a wooden ladle and five rulers. The natural debris such as leaves, seaweeds, and wood was brushed off from the samples and then transferred into aluminum boxes for further analyses. Thereafter, sediment samples were washed with distilled water in order to remove the sticky particles before sieve analysis and passed through mesh with diameter $0.038 \mathrm{~mm}$ in the laboratory. The particles of size $\geq 0.038 \mathrm{~mm}$ diameter was retained in the sieve. Later, samples were transferred into the Petri dish and put in oven at $60^{\circ} \mathrm{C}$ for 48 hours. Then, sieve analysis test was conducted. The beach sediments of sizes $0.5 \sim 0.25,0.25 \sim 0.125 \mathrm{~mm}$ was analyzed which emphasized the possible risk to marine organisms because of ingestion. The particles with size $<0.125 \mathrm{~mm}$ was not considered in present examination because of the difficulty of sieving for further analysis. Additionally, water samples were collected in $1 \mathrm{~L}$ glass bottle from seven stations (W1 - W7) along different beaches of the southern Shandong Peninsula during a similar period (Error! Reference source not found.). Five samples were collected from each station with five replications for each water sample. The seawater samples were collected about 45 to $50 \mathrm{~cm}$ from the surface. The size of microplastics in water samples was measured by Fiji Image, J software using freehand line tool option. Moreover, the sampling glass bottles were washed with deionized water in the laboratory to delaminate impurities and airborne fibers.

\section{Extraction of microplastics}

The extraction of microplastics from beach sediments was carried out according to density separation method. This method has been frequently employed in many studies (Jayasiri et al. 2013; Kim et al. 2015). In this method, sodium chloride $(\mathrm{NaCl})$ was taken as a saturated solution with an estimated density value of $1.172 \mathrm{~g} / \mathrm{cm}^{3}$. Here, $50 \mathrm{~g}$ of dried sand (sediment with grain sizes $0.5 \sim 0.25,0.25 \sim 0.125 \mathrm{~mm}$ for each sample) was mixed in $250 \mathrm{~mL}$ saturated solution of $\mathrm{NaCl}\left(1.172 \mathrm{~g} / \mathrm{cm}^{3}\right)$. The solution was stirred with a glass rod for about two to three minutes. Later, the solution was allowed to settle for 24 hours and finally passed through filter paper of $0.7 \mu \mathrm{m}$. Before analysis, the $\mathrm{NaCl}$ saturated solution was passed through filter paper $(5 \mu \mathrm{m})$ to remove the additional contamination of salt crystals. All transferring devices were washed with deionized water several times and, then passed through the same filter paper to minimize loss of microplastics due to adhesion on apparatuses walls. Finally, the filter paper was sealed under a cover glass to allow drying overnight for further analysis. In case of surface seawater samples, water samples were passed through sieve of $0.5 \mathrm{~mm}$ mesh before laboratory examination. Thus, acquired water samples were preserved at $4{ }^{\circ} \mathrm{C}$ till the analysis on next day (Leslie et al. 2017). Moreover, sediment and water samples were subjected to $30 \% \mathrm{H}_{2} \mathrm{O}_{2}$ to digest organic matter (Tamminga et al. 2019). $\mathrm{NaCl}$ was added in water samples to enhance density of solution (Thompson et al. 2004). Here, $5.0 \mathrm{~g}$ of $\mathrm{NaCl}$ was added for $50 \mathrm{~mL}$ of each sample. Thereafter, $1 \mathrm{~L}$ of water sample was passed through Whatman GF/C filter paper of $0.7 \mu \mathrm{m}$ size and sealed with glass cover to avoid external contamination and placed in glass sampling dish for drying around 24 hours at room temperature.

\section{Quantification and characterization of microplastics}

The identification of microplastics was done by stereo-microscope (Olympus SZ61 110AL2X-2 WD38) according to manufacturer's instructions (Hidalgo-Ruz et al. 2012). The microplastics falling in the following categories 
were considered as microplastics. For instance, a) Homogeneous and clear b) Evident color c) No organic structure. Overall, the filter paper was segregated into four equal parts to minimize counting error during the quantification process. Each filter paper was counted three to four times for the reliable outcomes. Moreover, the number of microplastics which were estimated via visual calculations on the filter paper was confirmed with Fiji Image j software.

\section{Polymers identification of microplastics}

A FTIR Tensor 27 (Bruker, Germany) spectroscopy identified the polymer composition of microplastics. To ensure accuracy and precision, five background pooled scans were accomplished before and after every 15 measurements. The obtained spectra were matched with different spectral libraries and self-collected spectra of prior published reports. We only spectra with $70 \%$ similarity index with reference spectra were considered. The scale of study was large and we randomly selected representative samples from beach sediments $(n=20)$ for each microplastic with $0.5 \sim 0.25$ and $0.25 \sim 0.125 \mathrm{~mm}$, and surface seawater samples $(\mathrm{n}=20)$ for FTIR analysis was done based on color. Four samples for each color were randomly selected to determine the polymer composition of microplastics for beach sediment and water samples. For example, White $(n=4)$, Blue $(n=4)$, Black $(n=4)$, Red $(n=4)$, and Others $(n=4)$.

\section{Methodology validation for microplastics color}

Based on color, microplastics were categorized into five groups: white, blue, black, red, and others. The white category included colorless and transparent microplastics. The blue group contained deep blue, light blue, deep green, and light green microplastics. The black category comprised transparent black, gray, and white-striped black microplastics. The red group possessed pink and purple microplastics, while other groups consisted of different color rather than above categories.

\section{Statistical and data analysis}

Probability plot, Levine test, and Shapiro Wilk tests were performed to determine the normality of data. One-Way ANOVA and Spearman's rank correlation was used to determine the significant difference and relationship between the number of microplastics related to grain size. Whereas, Two-Way ANOVA was performed to figure out the significant difference between the color categories of microplastics at different locations for both beach sediment sites (E1 - E13), and surface seawater stations (W1 - W7).

\section{Quality assurance (QA) and quality control (QC)}

All apparatus and instruments were washed with Milli Q water before performing the experiment. The sampling and experimental devices were covered with aluminum foil during laboratory work in order to avoid contamination. Therefore, non-textile robe, gloves, non-plastic tolls, and caps were used to minimize the effect of clothes and hairs. The door and windows of laboratory were closed during experiment. The filter paper was covered with glass to protect from air contamination. Moreover, the known sample of sodium and potassium bromide were run before FTIR analysis to ensure the validity of FTIR results. Ethanol was used to clean the germanium crystal of FTIR. 


\section{Abundance of microplastics in beach sediment}

164

165

166

167

168

169

170

171

172

173

174

175

176

177

178

179

180

181

182

183

184

185

186

187

188

189

190

191

192

193

194

195

196

197

The findings of present study showed that every sample in beach sediments possessed microplastics. The mean microplastic abundance of thirteen sites was approximately $664 \pm 80$ microplastic/kg dw with $0.5 \sim 0.25$ and $0.25 \sim 0.125 \mathrm{~mm}$. The median of microplastics was estimated to be 236 and 380 corresponding with grain size $0.5 \sim 0.25$ and $0.25 \sim 0.125 \mathrm{~mm}$, respectively. The microplastics with the size of $0.25 \sim 0.125 \mathrm{~mm}$ contained higher concentration of microplastics than those with size of $0.5 \sim 0.25 \mathrm{~mm}$. When the concentration of microplastics obtained from different beaches was compared, higher concentration of microplastics was noted for Bathing beach No.1 (E6), i.e. $716 \pm 72$, and $900 \pm 180$ microplastics $/ \mathrm{kg} \mathrm{dw}$ for $0.5 \sim 0.25$ and $0.25 \sim 0.125 \mathrm{~mm}$ followed by Wanpingkou bathing beach (E13) with $396 \pm 16$ and $352 \pm 52$ microplastics $/ \mathrm{kg}$ dw with $0.5 \sim 0.25$ and 0.25 0.125 $\mathrm{mm}$ and so on (See Error! Reference source not found. for comparison). Whereas, a lower concentration of microplastics $(172 \pm 12$, and $256 \pm 20$ microplastics $/ \mathrm{kg}$ dw with $0.5 \sim 0.25$ and $0.25 \sim 0.125 \mathrm{~mm})$ was found at Chengdao beach (E1). One-Way Anova results revealed a significant difference between the number of microplastics and sediments with grain size of $0.5 \sim 0.25,0.25 \sim 0.125 \mathrm{~mm}$. Spearman's rank correlation revealed a positive relationship between microplastic abundance and grain size. The abundance of microplastics increased with the decreasing grain size. It indicated that distribution and abundance of microplastics were statistically same among different sites.

\section{Abundance of microplastics in surface seawater}

Each beach sediment and sample of surface seawater contained microplastics. The average microplastic abundance for all stations (W1 - W7) was $5.6 \pm 0.4$ microplastics/L. A variation of microplastics was found at each station. The abundance and distribution of microplastics in surface seawater at different stations was presented in Error! Reference source not found.. Moreover, tolls of Fiji image J software were utilized to determine the size of microplastics for surface seawater. Microplastics sizes $<125 \mu \mathrm{m}$ had higher concentrations followed by $125 \sim 250$ and 250 500 $\mu \mathrm{m}$ (Error! Reference source not found.). Statistically significant difference was found between microplastic abundance and grain size.

\section{Color of Microplastics}

The variations in the colors of microplastics were observed in both surface seawater and beach sediments which were assigned five categories as discussed in the methodology section. The color of microplastics varied in beach sediments and surface seawater. Out of five categories, black microplastics were dominant (approximately 34\%) followed by white, blue, red and others accounted as $22 \%, 22 \%, 16 \%$ and $6 \%$ of beach sediment with $0.5 \sim 0.25$ $\mathrm{mm}$ for all sites. Similarly, sediment with $0.25 \sim 0.125 \mathrm{~mm}$ contained mostly white microplastics (37\%) followed by back, blue, red, and others represented by $28 \%, 16 \%, 13 \%$, and $6 \%$. Besides, the highest proportion of white microplastics was observed at E9 (48\%) and the lowest in E8 (21\%). Additionally, greater proportion of black microplastics was estimated to be $52 \%$ at W4 and the lowest in W3 accounting 28\%. Overall, black microplastics were dominant (40\%), followed by blue, white, red and others comprising 24\%, 17\%, 13\%, and 6\% (Error! Reference source not found.). 


\section{Shape of Microplastics}

199

200

201

202

203

204

205

206

207

208

209

210

211

212

213

214

215

216

217

218

219

220

221

222

223

224

225

226

227

228

229

230

231

232

233

234

235

Fibers were the dominant shape in both sediment and seawater. These fibers possessed multiple colors as discussed in the previous section. Out of $100 \%$, average microplastic abundance, approximately $97 \%$ were fibers, and remaining were others including fragments in beach sediments at different sites which was similar to surface seawater (Error! Reference source not found.). Moreover, no statistical difference was noticed within the fibers and other microplastics for both beach and seawater at different stations.

\section{Polymer identification of microplastics}

Numerous spectral peaks attained by FTIR spectroscopy which were in the range of $400 \sim 4000 \mathrm{~cm}^{-1}$ due to the presence of microplastics. These spectral peaks attributed to different functional groups. The different spectral peaks on various wavelengths demonstrated the existence of multiple features such as vibrations, stretching, bounding, and aromatic rings containing different elements. The most common microplastic polymers included polypropylene (PP), polyethylene (PE), polystyrene (PS) with density ranges of 0.895 0.92, 0.93 0.97, and $0.96 \sim 1.05 \mathrm{~g} / \mathrm{cm}^{3}$ ) in beach sediments and surface seawater. The densities of these polymers were similar to the density of water (Hidalgo-Ruz et al., 2012). In Error! Reference source not found.a, sharp peaks were observed at $2915 \mathrm{~cm}^{-1}, 2848 \mathrm{~cm}^{-1}$ and $1465 \mathrm{~cm}^{-1}$ belong with $-\mathrm{CH}_{2}-$ vibration. The peak at $721 \mathrm{~cm}^{-1}$ attributed to $-\mathrm{CH}_{2}-$ in-plane oscillating vibration. Therefore, acquired spectra were PE (Error! Reference source not found.a). Similarly, Error! Reference source not found.b comprised of three peaks at $1377 \mathrm{~cm}^{-1}, 1156 \mathrm{~cm}^{-1}$ and $971 \mathrm{~cm}^{-1}$ due to $-\mathrm{CH}_{3}$ and $-\mathrm{CH}_{2}-$ vibration with peaks at $2953 \mathrm{~cm}^{-1}, 2917 \mathrm{~cm}^{-1}, 2845 \mathrm{~cm}^{-1}$ and $1459 \mathrm{~cm}^{-1}$. Thus, the obtained spectra were PP (Error! Reference source not found.b). Furthermore, Error! Reference source not found.c showed the spectra of PS though several sharp peaks developed at different absorbance bands. For example, sharp peaks at $3024 \mathrm{~cm}^{-1}$, and $2847 \mathrm{~cm}^{-1}$ showed C-H stretches, and $1601 \mathrm{~cm}^{-1}, 1492 \mathrm{~cm}^{-1}$ attributed to the aromatic rings, and $1041 \mathrm{~cm}^{-1}, 1027 \mathrm{~cm}^{-1}$ and $694 \mathrm{~cm}^{-1}$ were because of $-\mathrm{CH}_{2}-$ and aromatic $\mathrm{CH}$ bend. The absorption of determining polymers was identified via spectral libraries and direct matching of prior attained spectra (Verleye et al. 2001; Nishikida and Coates 2003; Noda et al. 2007; Asensio et al. 2009). PS was more abundant polymer than PP and PE in both beach and water samples. The percentage of PS was estimated to be $50 \%, 40 \%$ beach sites with $0.5 \sim 0.25,0.25 \sim 0.125 \mathrm{~mm}$, and $40 \%$ in seawater followed by PP and PE. The proportion of these polymers was based on color as shown in Error! Reference source not found.

\section{Discussion}

The concentration of microplastics was found ubiquitous on designated beaches and surface seawaters in the present study. The higher concentration of microplastics in beach sediments than surface seawater might be due to regular and long-term accumulation via ocean currents including terrestrial origin. Whereas, the lesser concentration of microplastics in surface seawater could be attributed to numerous factors such as hydrodynamics, sample handling method, ocean gyres, tides, rainfall, wind and sampling season etc. (Kukulka et al. 2012) documented several factors that could influence the abundance and distribution of microplastics. These factors were wind (Collignon et al. 2012), storm (Lattin et al. 2004), shape, size, density, and settling velocity of microplastics in the water column (Khatmullina and Isachenko 2017). Moreover, there is no specified criterion and methodology for the collection, quantification, and characterization of microplastics (Besley et al. 2017). It was not easy to outline relationship between microplastic abundance with previous studies elsewhere. The findings 
of present study were compared with other studies which applied similar units for quantification of microplastics for beach sediments (microplastics $/ \mathrm{kg} \mathrm{dw}$ ), and surface water (microplastics/L). The microplastic abundance along the beaches of southern Shandong was not uniform in comparison to the previous studies (Error! Reference source not found.). For instance, the mean microplastics on the southern Shandong beaches was $664 \pm 80$ microplastics $/ \mathrm{kg} \mathrm{dw}$, compared with 261 microplastics $/ \mathrm{kg} \mathrm{dw}$ on the Caribbean beaches (Bosker et al. 2018) and 248 microplastics $/ \mathrm{kg} \mathrm{dw}$ on the European beaches (Lots et al. 2017). These coastlines contained lesser concentration of microplastics than the southern Shandong beaches. Whereas, Halifax Harbor, Canada, Venice Lagoon, and Puducherry Coast was contaminated with higher microplastics concentration i.e. 4500, $720.30 \pm$ 191.60, 1454 microplastics $/ \mathrm{kg}$ dw. Out of designated beaches, the Bathing beach No.1 (E6) contained higher concentration of microplastics i.e. $716 \pm 72$ microplastics $/ \mathrm{kg} \mathrm{dw}, 900 \pm 180$ microplastics $/ \mathrm{kg} \mathrm{dw}$ with $0.5 \sim 0.25$, and $0.25 \sim 0.125 \mathrm{~mm}$ than other beaches. Overall, variation of microplastics at different sites whether globally or locally seemed due to numerous reasons. The concentrations of microplastics were linked with population density and beachgoers (Pedrotti et al. 2016). Low concentration of microplastics could be due to lesser anthropological activities (Nor and Obbard 2014), though these activities were the primary source of micro-pollutants distribution (Vianello et al. 2013), including industrialization, urbanization, sampling procedure, sampling season with natural factors like, wind, rainfall, storms and geographic proximity of the region. For example, the concentration of microplastics was significantly greater on windward beaches than leeward beaches (Monteiro et al. 2018). For the present study, the higher microplastics concentration at Bathing beach No.1 (E6) might be due to immense swimming, shipping, fishing, and beachgoers activities with some other factors during sampling period. Moreover, the determination of the absolute information about variations of microplastics on the beaches of Shandong Peninsula than other beaches elsewhere was challenging task due to diverse anthropogenic and natural factors.

The average microplastic abundance of sea water was estimated to be $5.6 \pm 0.4$ microplastics $/ \mathrm{L}$ which was moderate than many studies elsewhere (Error! Reference source not found.). The variation of microplastics distribution in maritime environment involved multiple factors comprising weather, hydrology, physiochemical, and biological processes that make it difficult to predict mode of microplastics in marine environment (Khatmullina and Chubarenko 2019). In addition, the higher salinity enhances buoyancy which supports floating of microplastics on surface of seawater. The Yellow Sea encompass numerous currents (Liu et al. 2015), which vary in different seasons (Xu et al. 2018). These currents could distribute different materials including microplastics (Jilan 2004). Thus, it has been hypothesized that difference in microplastic abundance in the present study might be different due to multiple hydrological features than elsewhere. The presence of microplastics in surface seawater of the Yellow Sea near coastal regions of the southern Shandong showed that, microplastics accumulation on different beaches occurred via ocean currents and tides. Moreover, beachgoers, urban run-off, sewage discharge, recreational, shipping, swimming activities, industrialization, and urbanization have significant role in variability of microplastics. Moreover, we also found few recent studies about different aspects of microplastics that encompass the Yellow Sea. Likewise, characterization and distribution of microplastics (Jiang et al. 2020b), investigation of microplastics in the digestive tract of marine species (Sun et al. 2019), zooplankton (Sun et al. 2018), prevalence of microplastics in sediment and benthic organism (Guo and Wang 2019), offshore sediment (Zhang et al. 2018). 
Importantly, the present study showed that the majority of microplastics was fibers and very few were others in beach sediments and surface seawater. Our findings were underlined with prior outcomes of Caribbean, European, and Mexico beaches (Error! Reference source not found.). Those studies found fibers to have higher percentage (>90\%) of microplastics (Lots et al. 2017; Bosker et al. 2018). Immense human activities produce microfibers during washing, production, and natural aging in textile industries. A huge amount of fibers enters into marine environment along sewage discharge without proper treatment, high development and industrialization (Zhao et al. 2018). The microplastics were noticed multicolor in this study which showed different sources of microplastics. The color of microplastics has been used to determine their origin in different environments ( $\mathrm{Li}$ et al. 2018). For example, microplastics with blue, violet, red, or green color were commonly made of polyester and acrylic (de Jesus Piñon-Colin et al. 2018). Similarly, white microplastics were composed of PP though translucent microplastics were mainly composed of PE on La Graciosa Island, Spain (Edo et al. 2019). Microplastics color is a crucial feature assessing the adsorption relationship and interaction with couple of species and was intended that dark black microplastics with multicolored microplastics had greater chances of ingestion as food by mistake (Ory et al. 2017). The presence of different microplastics colors revealed the possible hazard and risk to marine species along the southern Shandong Peninsula. Moreover, it could directly affect human health through the consumption of different marine species. FTIR analysis of this study showed the prevalence of PE, PS, and PP in surface seawater and beach sediments. These polymers were recognized more prominently in different coastal and marine environments (Simon-Sánchez et al. 2019). The large quantity of these polymers in coastal and marine environments was due to immense aquaculture, agriculture, and rapid industrial developments (Facts 2019). Out of these polymers, PE was more common and utilized in food packing, agricultural films, plastic bags, ties, clothes, ropes, carpets, and bottles. While, PP was an integral part of food packing, pipes, carpets, straws, water bottle caps, and plastic containers. PS was primarily used in plates, disposable cups, textile industry, and Styrofoam material. The existence of higher percentage of these polymers (PE, PP, and PS) in maritime environment might be due to higher output which possessed less density than water and float on the surface water (Europe 2015). These polymers were also being produced on the account of global plastic production and discharge into the sea without proper treatment involving local sources such as local industrial waste, urbanization, disposal of sewage waste, fishing and shipping etc (Lots et al. 2017). The polymers on the southern Shandong beaches could be transported via ocean currents or tides and then accumulated with the process of sedimentation. In last, the findings of this study will assist to develop a better understanding of microplastics occurrence including source and pathways in marine and coastal zones of the southern Shandong Peninsula. It also facilitates establishing better monitoring system and provides beneficial data to evaluate the possible risk to the coastal zone and marine ecosystems caused by microplastics. A detailed investigation on microplastics would be beneficent regarding marine food-related species including fishes along the southern part of the Yellow Sea to assess possible risk to human health due to the consumption of microplastics via seafood. Moreover, the effect of microplastics on the properties of these beaches is yet unknown. We highly recommend the utilization of different simulation models to conduct field surveys for sake of measuring an actual magnitude of plastic pollution at a global scale considering biological processes, coupled with physical-biological models for marine microplastics. The sampling and analysis method should be globally standardized for better comparison of the microplastic abundance among different regions. We used method which only detect the microplastics with density $<1.17 \mathrm{~g} / \mathrm{cm}^{3}$. Therefore, we 
314 were unable to determine the polymers with high density such as polyethylene terephthalate, rayon, polyvinyl

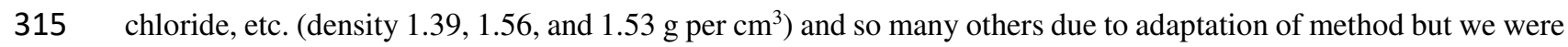

316 still capable to segregate the most common polymers which have been identified worldwide.

\section{Conclusion}

318 Identification, characterization, and quantification of microplastics were analyzed on thirteen beaches of the 319 southern Shandong and seven stations in the surface seawater of the southern Yellow Sea. The mean abundance

320 of microplastics was approximately $664 \pm 80$ microplastics $/ \mathrm{kg} \mathrm{dw}$ in beach sediment and $5.62 \pm$

3210.49 microplastics/L in surface seawater. The concentration of microplastics increased with decrease of their grain

322 sizes. The prominent morphology of microplastics was fibers with few fragments. The color of microplastics for 323 both sediments and surface seawater was mainly white, black, blue, and red constituting PP, PE, and PS polymer

324 composition. The source of microplastics on the beaches might be ocean currents or tides and some terrestrial 325 origin. Whereas, global and local sources such as disposal of industrial wastes, sewage waste etc. without proper 326 treatment could be other source of microplastics to the Yellow Sea. This study provides comprehensive and novel 327 data on the microplastics distribution on different beaches of the southern Shandong Peninsula that allude to 328 proper mitigation and monitoring plans to overcome microplastics risk of the coastal and marine ecosystems.

329 Otherwise, the number of microplastics would keep on increasing dramatically which would have severe 330 consequences to marine species including human health. 


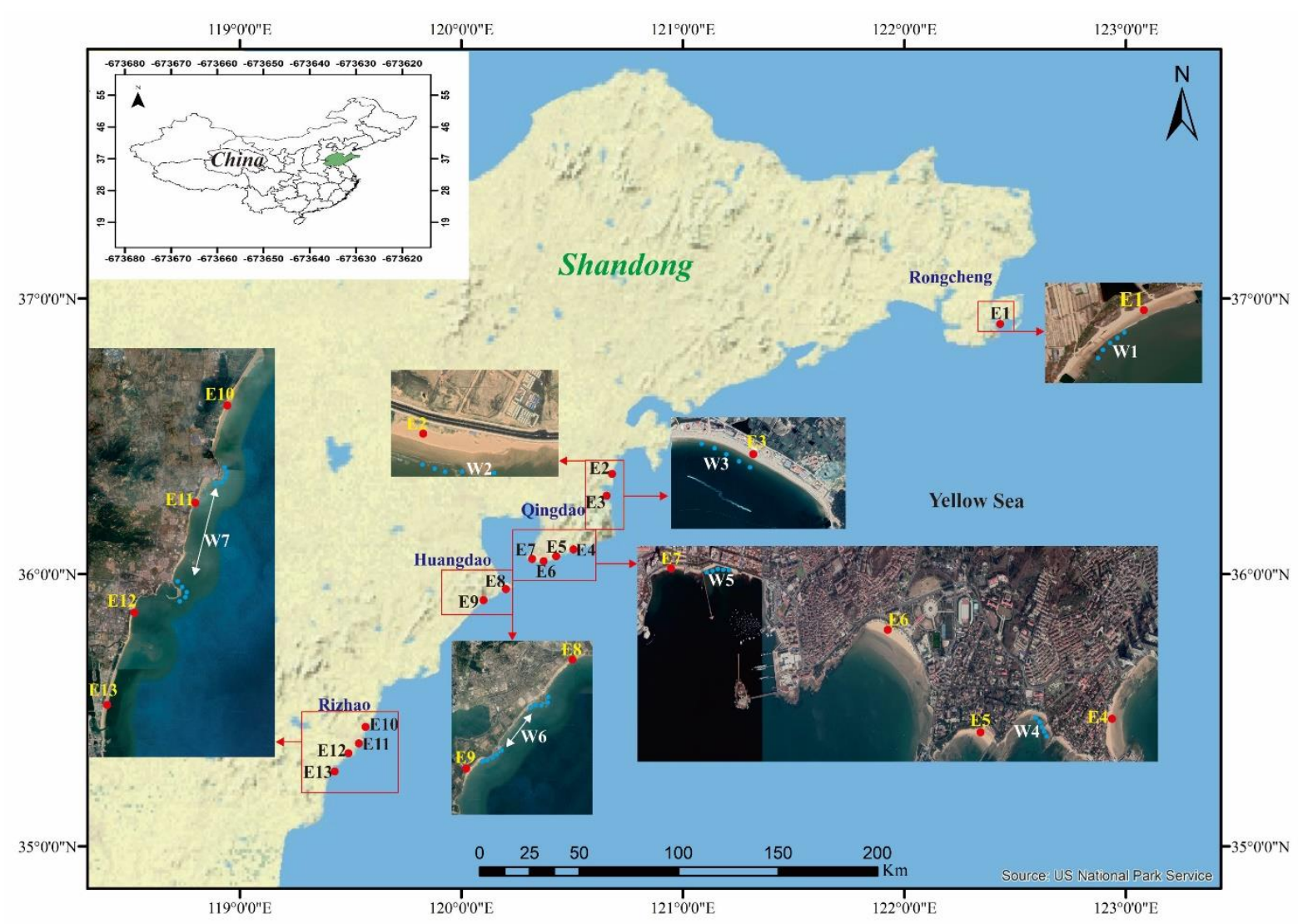

Fig 1 Map of the study area. W1 -W7 represent then surface seawater stations, and E1 - E13 denotes the beach sites.

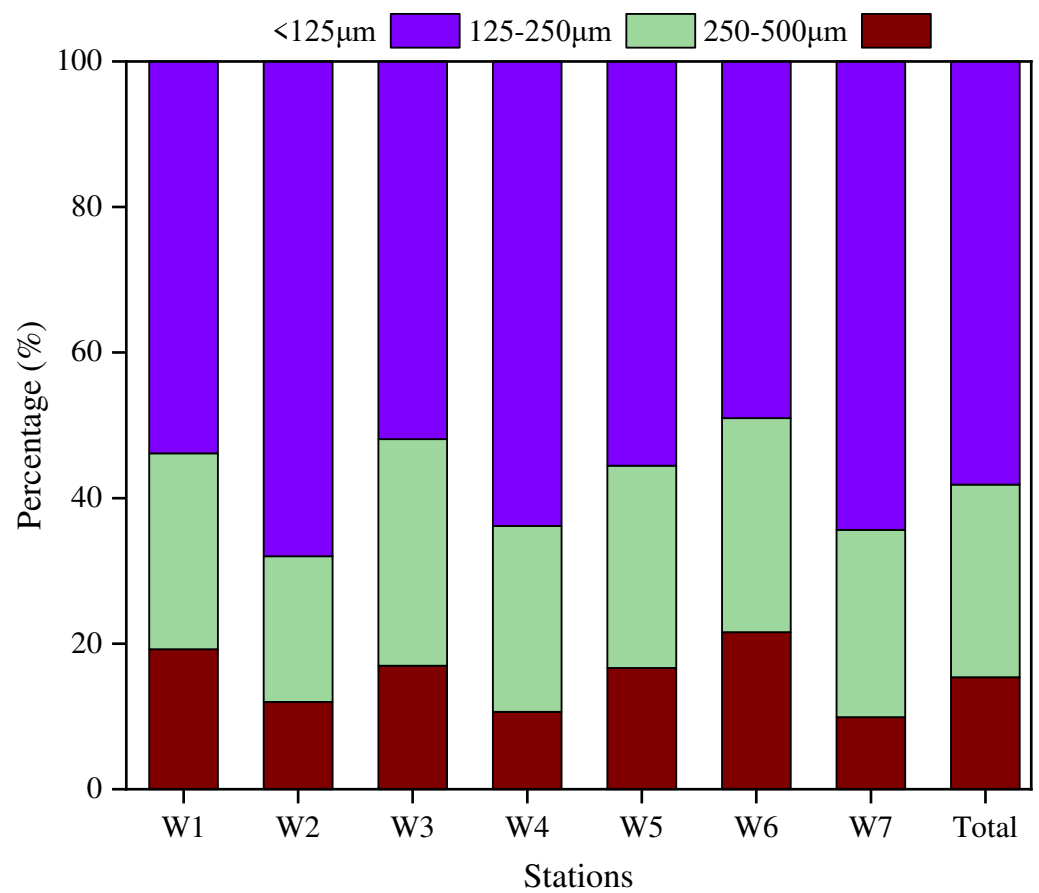

Fig 2 The microplastic abundance and sizes at various stations. The size of microplastics for surface seawater samples was determined by Fiji Image J software. 


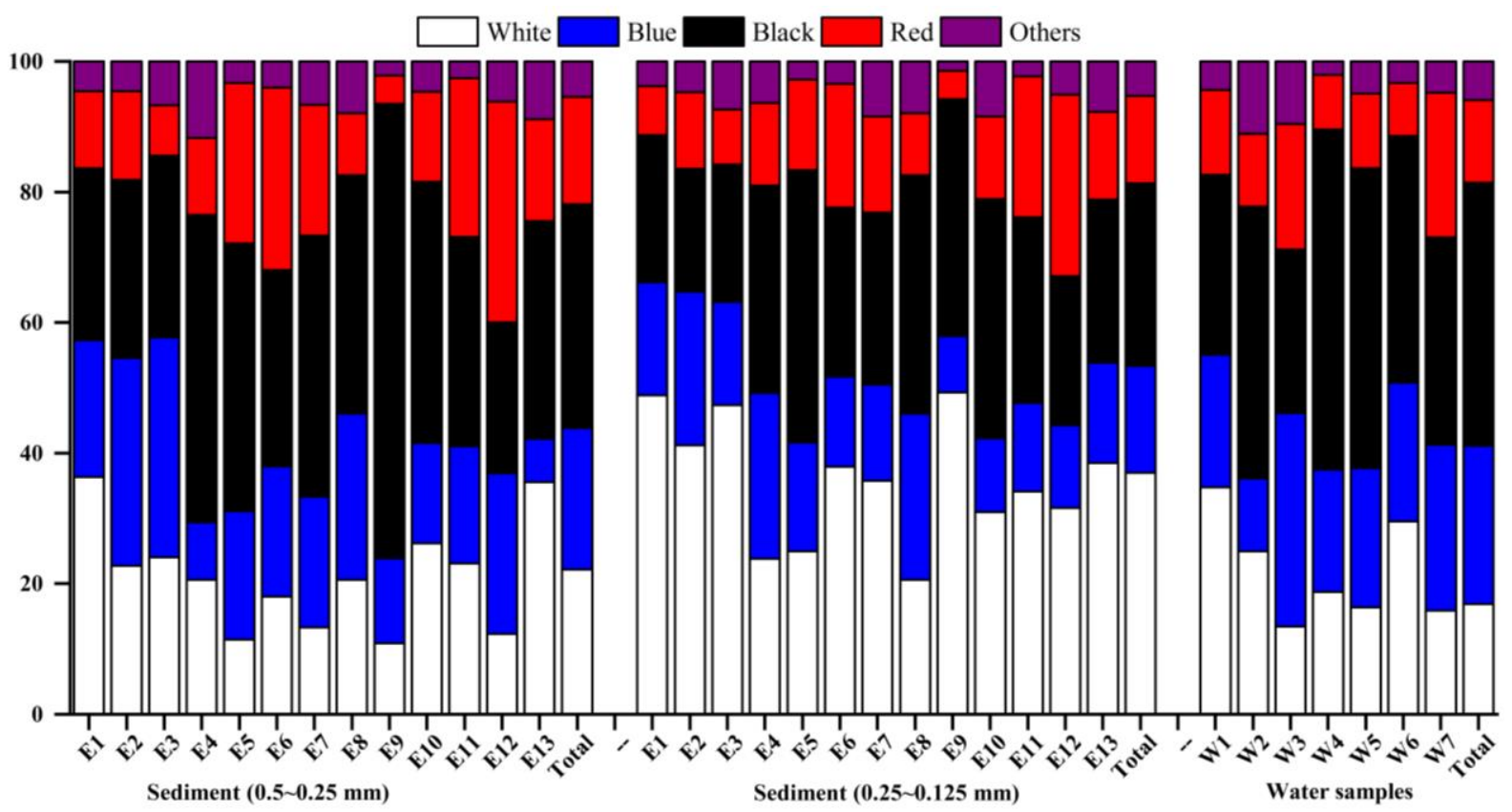

Fig 3 The proportion of different color of beach sediments and water samples at different sites. 

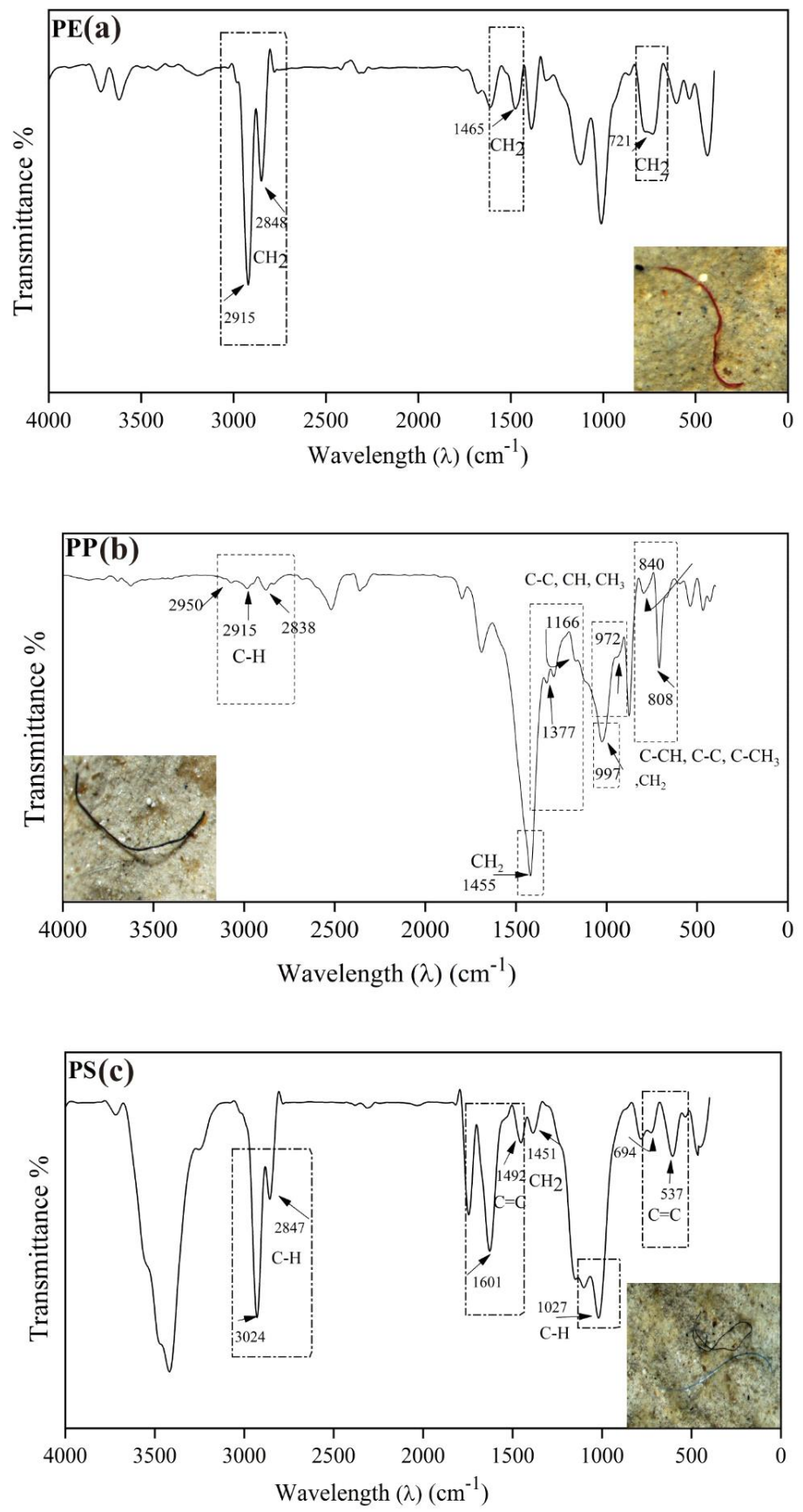

Fig 4 Illustration of the spectra of microplastics polymers including peaks of (polyethylene (PE), polypropylene $(P P)$, polystyrene (PS)) from both surface seawater and beach sediments via FTIR spectroscopy. 

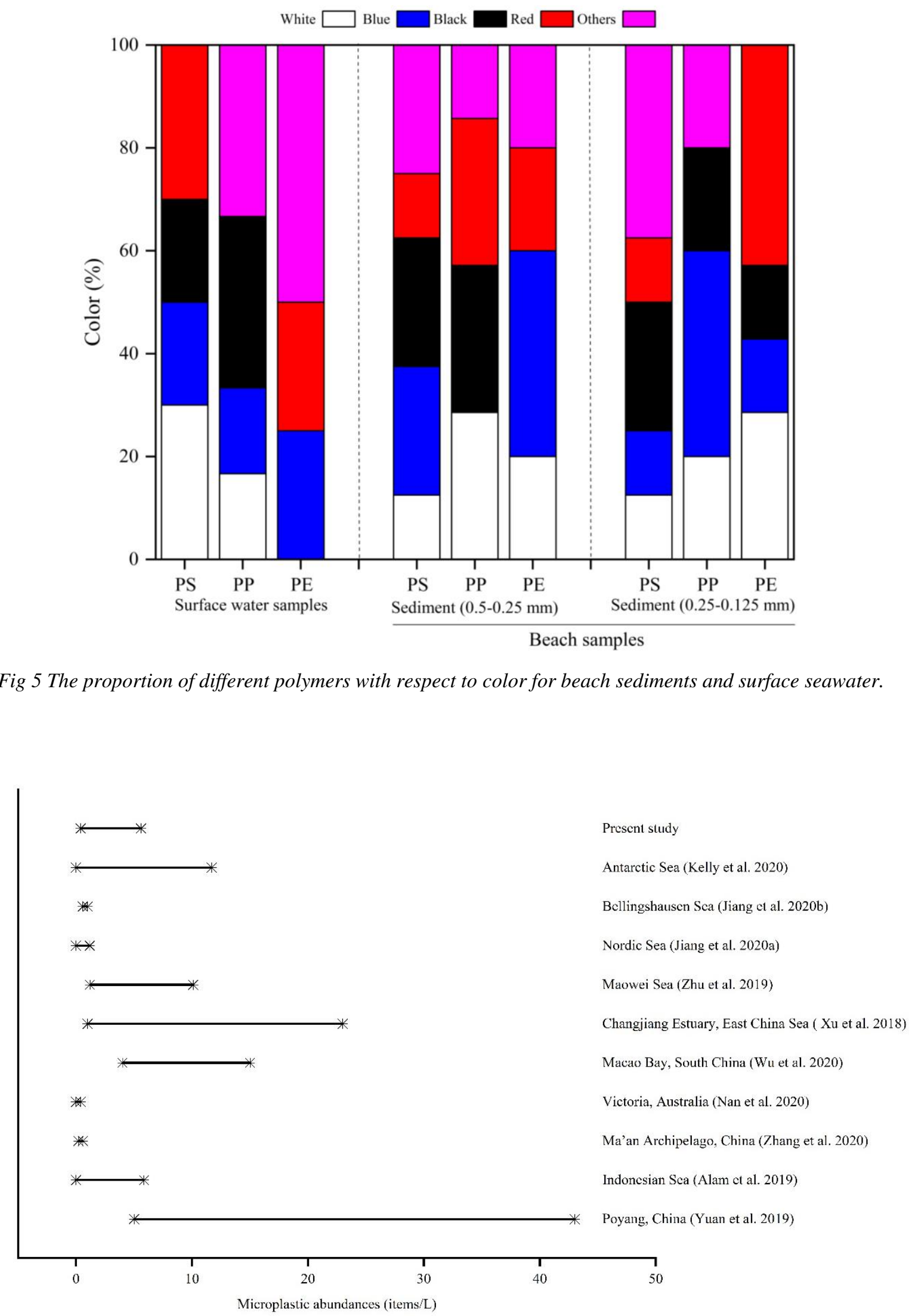

Fig 6 Microplastic abundance in different seas including present study. 
Table 1 Microplastic abundance and type of beach sediments with different grain sizes. Results are presented from different sites and assigned (E1-E13) to represent each site. Microplastic abundance of each site was taken as an average number of microplastics from 5 replications per kg of the dry sediment (dw) ( \pm SEM). Microplastics (Mps) are classified between fibers and others and expressed in proportion of total count.

\begin{tabular}{|c|c|c|c|c|}
\hline \multirow{2}{*}{ Location } & \multirow{2}{*}{$\begin{array}{l}\text { Sediment grain size } \\
(\mathrm{mm})\end{array}$} & \multirow[b]{2}{*}{$\mathrm{Mps} / \mathrm{kg} \mathrm{dw}$} & \multicolumn{2}{|c|}{ Mps Type } \\
\hline & & & Fibers $(\%)$ & Others $(\%)$ \\
\hline \multirow{2}{*}{ E1 (Chengdao beach) } & $0.5 \sim 0.25$ & $172 \pm 12$ & 96 & 4 \\
\hline & $0.25 \sim 0.125$ & $256 \pm 20$ & 97 & 3 \\
\hline \multirow{2}{*}{ E2 (Aoshan beach) } & $0.5 \sim 0.25$ & $180 \pm 12$ & 97 & 3 \\
\hline & $0.25 \sim 0.125$ & $352 \pm 16$ & 97 & 3 \\
\hline \multirow{2}{*}{ E3 (Yangkou beach) } & $0.5 \sim 0.25$ & $252 \pm 24$ & 97 & 3 \\
\hline & $0.25 \sim 0.125$ & $380 \pm 60$ & 98 & 2 \\
\hline \multirow{2}{*}{ E4 (Bathing beach 3) } & $0.5 \sim 0.25$ & $200 \pm 12$ & 97 & 3 \\
\hline & $0.25 \sim 0.125$ & $300 \pm 32$ & 98 & 2 \\
\hline \multirow{2}{*}{ E5 (Bathing beach 2) } & $0.5 \sim 0.25$ & $192 \pm 16$ & 98 & 2 \\
\hline & $0.25 \sim 0.125$ & $388 \pm 28$ & 98 & 2 \\
\hline \multirow{2}{*}{ E6 (Bathing beach No.1) } & $0.5 \sim 0.25$ & $716 \pm 72$ & 96 & 4 \\
\hline & $0.25 \sim 0.125$ & $900 \pm 180$ & 97 & 3 \\
\hline \multirow{2}{*}{ E7 (Zhanqiao beach) } & $0.5 \sim 0.25$ & $240 \pm 28$ & 97 & 3 \\
\hline & $0.25 \sim 0.125$ & $368 \pm 72$ & 97 & 3 \\
\hline \multirow{2}{*}{ E8 (Golden bathing beach) } & $0.5 \sim 0.25$ & $244 \pm 20$ & 97 & 3 \\
\hline & $0.25 \sim 0.125$ & $440 \pm 48$ & 97 & 3 \\
\hline \multirow{2}{*}{ E9 (Silver beach) } & $0.5 \sim 0.25$ & $260 \pm 20$ & 97 & 3 \\
\hline & $0.25 \sim 0.125$ & $420 \pm 140$ & 97 & 3 \\
\hline \multirow{2}{*}{$\begin{array}{l}\text { E10 (Forest park bathing } \\
\text { beach) }\end{array}$} & $0.5 \sim 0.25$ & $224 \pm 12$ & 96 & 4 \\
\hline & $0.25 \sim 0.125$ & $396 \pm 40$ & 98 & 2 \\
\hline \multirow{2}{*}{ E11 (Dachenjia beach) } & $0.5 \sim 0.25$ & $212 \pm 8$ & 97 & 3 \\
\hline & $0.25 \sim 0.125$ & $260 \pm 24$ & 98 & 2 \\
\hline \multirow{2}{*}{$\begin{array}{l}\text { E12 (Dongxiaozhuang } \\
\text { beach) }\end{array}$} & $0.5 \sim 0.25$ & $236 \pm 16$ & 96 & 4 \\
\hline & $0.25 \sim 0.125$ & $404 \pm 36$ & 97 & 3 \\
\hline \multirow{2}{*}{$\begin{array}{l}\text { E13 (Wanpingkou bathing } \\
\text { beach) }\end{array}$} & $0.5 \sim 0.25$ & $396 \pm 16$ & 96 & 4 \\
\hline & $0.25 \sim 0.125$ & $352 \pm 52$ & 97 & 3 \\
\hline Overall Mps mean & & $664 \pm 80$ & 97 & 3 \\
\hline
\end{tabular}


Table 2 The microplastic abundance was taken as total mean of each station for $(N)$ number of samples with 5 replications and expressed in mean $\left(L^{-1}\right)$ with standard error mean (SEM) of surface seawater. A symbol (W1 $W 7)$ is given to represent each station.

\begin{tabular}{lcccc}
\hline Region Name & N & Microplastics mean $\left(\mathrm{L}^{-1}\right)$ & \% Fibers & \% Others \\
\hline W1 (Chengdao beach) & 5 & $4 \pm 0.4$ & 97 & 3 \\
W2 (Aoshan beach) & 5 & $4.6 \pm 0.6$ & 98 & 2 \\
W3 (Yangkou beach) & 5 & $5.4 \pm 0.6$ & 97 & 3 \\
W4 (Bathing beach 2 \& 3) & 10 & $5 \pm 0.5$ & 97 & 3 \\
$\begin{array}{l}\text { W5 (Bathing No.1 \& } \\
\text { Zhanqiao beach) }\end{array}$ & 10 & $9.2 \pm 0.4$ & 97 & 3 \\
$\begin{array}{l}\text { W6 (Golden \& Silver } \\
\text { beach) }\end{array}$ & 10 & $6 \pm 0.4$ & 98 & 2 \\
W7 (Rizhao coastal area) & 10 & $5.2 \pm 0.2$ & 96 & 4 \\
Overall, mean value & 55 & $5.6 \pm 0.4$ & 97 & 3 \\
\hline
\end{tabular}


Table 3 Mean grain size of microplastics contents along different beaches worldwide (Particles per $\mathrm{kg} d w$ ).

\begin{tabular}{lcccr}
\hline Location & $\begin{array}{c}\text { Sediment } \\
\text { size }(\mathrm{mm})\end{array}$ & Mean & Median & Sources \\
\hline Hongkong & $2 \sim 0.063$ & 16.8 & 5 & (Lo et al. 2018) \\
Belgium & $1 \sim 0.038$ & 134 & - & (Claessens et al. 2011) \\
Beibu Gulf, China & $<0.5$ & 6870 & 6140 & (Qiu et al. 2015) \\
Caribbean & $<0.5$ & $261 \pm 6$ & 276 & (Bosker et al. 2018) \\
European & $<1$ & 248 & 143 & (Lots et al. 2017) \\
$\begin{array}{l}\text { Persian Gulf } \\
\text { Halifax Harbor, Canada }\end{array}$ & $0.5 \sim 0.063$ & 4500 & 3950 & (Naji et al. 2017) \\
Isle of Rügen, & $>0.01$ & $61 \pm 49$ & - & (Mathalon and Hill 2014) \\
Germany & 93.0 & 88.1 & (Hengstmann et al. 2018) \\
Puducherry Coast & $1 \sim 0.3$ & $720 \pm 192$ & - & (Dowarah and Devipriya 2019) \\
Qatar & $1 \sim 5$ & $6-38(13.5)$ & - & (Abayomi et al. 2017) \\
Venice Lagoon, Italy & $<1$ & 1445 & 1435 & (Vianello et al. 2013) \\
Shandong, China & $\mathbf{0 . 5 ~ 0 . 1 2 5}$ & $664 \pm 80$ & $\mathbf{3 0 8}$ & Present study \\
\hline
\end{tabular}


Table 4 Prior investigations about microplastics concerning different characteristics worldwide.

\begin{tabular}{|c|c|c|c|c|}
\hline Country & Types of microplastics & Color & Chemical composition & Reference \\
\hline Brazil & $\begin{array}{l}\text { Fragments (56\%), Foam (26.7\%), Pellet } \\
(9.9 \%)\end{array}$ & $\begin{array}{l}\text { Fibers: blue, red and green. Pellets: } \\
\text { translucent }\end{array}$ & $\begin{array}{l}\text { Fibers PP, Nylon \& Polyvinyl } \\
\text { alcohol. PS }(26.7 \%)\end{array}$ & $\begin{array}{l}\text { (de Carvalho and Neto } \\
\text { 2016) }\end{array}$ \\
\hline Colombia & Pellet & $\begin{array}{l}\text { White }(65.07 \%) \text {, other, }(24.26 \%) \text {, } \\
\text { gray }(3.83 \%)\end{array}$ & $\mathrm{PE}$ and $\mathrm{PP}$ & $\begin{array}{l}\text { (Acosta-Coley and } \\
\text { Olivero-Verbel 2015) }\end{array}$ \\
\hline Europe & $\begin{array}{l}\text { Fibers }(98.7 \%) \text {, Particles }(0.91 \%) \text {, Film } \\
(0.35 \%)\end{array}$ & $\begin{array}{l}\text { Blue/black }(77.5 \sim 82.9 \%) \text {, red } \\
(9.3 \sim 13.6 \%)\end{array}$ & $\begin{array}{l}\text { Polyester (70 \%), PP (20\%), PE } \\
(10 \%)\end{array}$ & (Lots et al. 2017) \\
\hline India & $\begin{array}{l}\text { Fragments }(47-50 \%) \text {, Fibers }(24 \sim 27 \%) \text { and } \\
\text { Foam }(10 \sim 19 \%)\end{array}$ & N. R & $\begin{array}{l}\text { PE (45.98 \%), PP (19.41\%), PS } \\
(17.41 \%)\end{array}$ & (Karthik et al. 2018) \\
\hline Mexico & $\begin{array}{l}\text { Fibers (91 \%), Film (5\%), Spheres (toys) } \\
(3 \%)\end{array}$ & $\begin{array}{l}\text { Fibers: black }(59 \%) \text { and blue }(25 \%) \text {. } \\
\text { Others: }(12 \%)\end{array}$ & $\begin{array}{l}\text { Polyacrylamide, Nylon, } \\
\text { Polyacrylate }\end{array}$ & $\begin{array}{l}\text { (de Jesus Piñon-Colin et al. } \\
\text { 2018) }\end{array}$ \\
\hline Mexico & $\begin{array}{l}\text { Foams (15\%), Fibers }(11 \%) \text {, Rigid and } \\
\text { semirigid fragments }(56 \%) \text {, Film fragments } \\
(10 \%) \text {, Pellets and ammunition for toys } \\
(8 \%)\end{array}$ & $\begin{array}{l}\text { White }(23 \%) \text {, green }(17 \%) \text {, blue } \\
(17 \%) \text {, yellow }(16 \%) \text {, transparent } \\
(11 \%) \text {, red }(6 \%) \text {, others }(10 \%)\end{array}$ & $\begin{array}{l}\text { PE }(56 \%), \text { PP }(21 \%), \text { PS (12\%), } \\
\text { others (11\%) }\end{array}$ & $\begin{array}{l}\text { (Alvarez-Zeferino et al. } \\
\text { 2020) }\end{array}$ \\
\hline Caribbean & Fibers (> $95 \%)$, Others $(5 \%)$ & N. R & N. R & (Bosker et al. 2018) \\
\hline Portugal & Fibers $(80.64 \%)$ and Fragments $(19.63 \%)$ & Fibers: red, green, blue and black. & $\begin{array}{l}\text { Fibers: Rayon (81 \%). Fragments: } \\
\text { PP }(19.36 \%)\end{array}$ & (Frias et al. 2016, p. 20) \\
\hline Shandong & Fibers $(98 \%)$, and Fragments (2\%) & $\begin{array}{l}\text { Transparent, blue, red, black, and } \\
\text { others }\end{array}$ & PP, PE and PS & Present study \\
\hline
\end{tabular}




\section{Funding}

356 This study was funded by the National Key Research and Development Program (2016YFC0402602), the Ocean

357 Public Welfare Scientific Research Project by the State Oceanic Administration of the People's Republic of China

358 (grant no. 201405037), and the National Natural Science Foundation of China (grant nos. 41376054, 41176039

359 and 41410304022).

\section{Author contributions}

361 Rashid Pervez: Conceptualization, Formal analysis, Investigation, Writing - review \& editing. Yonghong Wang:

362 Supervision, ZhongPeng Lai: English Editing and proof reading.

\section{Data availability}

364 The datasets used and/or analyzed during the current study are available from the corresponding author on 365 reasonable request.

\section{Declarations}

367 Ethical approval

368 Not applicable

\section{Consent to participate}

370 Informed consent was obtained from all individual participants included in the study.

\section{Consent to participate}

372 Not applicable

\section{Competing interest}

374 The authors declare no conflict of interest. 
References:

Abayomi OA, Range P, Al-Ghouti MA, et al (2017) Microplastics in coastal environments of the Arabian Gulf. Marine Pollution Bulletin 124:181-188

Acosta-Coley I, Olivero-Verbel J (2015) Microplastic resin pellets on an urban tropical beach in Colombia. Environmental Monitoring and Assessment 187:435

Ajith, N., Arumugam, S., Parthasarathy, S. et al (2020). Global distribution of microplastics and its impact on marine environment a review. Environmental Science \& Pollution Research 27, 25970-25986.

Alam FC, Sembiring E, Muntalif BS, Suendo V (2019) Microplastic distribution in surface water and sediment river around slum and industrial area (case study: Ciwalengke River, Majalaya district, Indonesia). Chemosphere 224:637-645

Alvarez-Zeferino JC, Ojeda-Benítez S, Cruz-Salas AA, et al (2020) Microplastics in Mexican beaches. Resources, Conservation and Recycling 155:104633

Anbumani, S., Kakkar, P (2018) Ecotoxicological effects of microplastics on biota: a review. Environmental Science \& Pollution Research 25, 14373-14396.

Andrady AL (2017) The plastic in microplastics: A review. Marine Pollution Bulletin 119:12-22

Asensio RC, Moya MSA, de la Roja JM, Gómez M (2009) Analytical characterization of polymers used in conservation and restoration by ATR-FTIR spectroscopy. Analytical and Bioanalytical Chemistry 395:2081-2096

Barletta M, Lima AR, Costa MF (2019) Distribution, sources and consequences of nutrients, persistent organic pollutants, metals and microplastics in South American estuaries. Science of the Total Environment 651:1199-1218

Besley A, Vijver MG, Behrens P, Bosker T (2017) A standardized method for sampling and extraction methods for quantifying microplastics in beach sand. Marine Pollution Bulletin 114:77-83

Bosker T, Guaita L, Behrens P (2018) Microplastic pollution on Caribbean beaches in the Lesser Antilles. Marine Pollution Bulletin 133:442-447

Browne MA, Galloway TS, Thompson RC (2010) Spatial patterns of plastic debris along estuarine shorelines. Environmental Science \& Technology 44:3404-3409

Caruso, G., Pedà, C., Cappello, S. et al (2018) Effects of microplastics on trophic parameters, abundance and metabolic activities of seawater and fish gut bacteria in mesocosm conditions. Environmental Science \& Pollution Research 25, 30067-30083.

Claessens M, De Meester S, Van Landuyt L, et al (2011) Occurrence and distribution of microplastics in marine sediments along the Belgian coast. Marine Pollution Bulletin 62:2199-2204

Collignon A, Hecq J-H, Glagani F, et al (2012) Neustonic microplastic and zooplankton in the North Western Mediterranean Sea. Marine Pollution Bulletin 64:861-864

de Carvalho DG, Neto JAB (2016) Microplastic pollution of the beaches of Guanabara Bay, Southeast Brazil. Ocean \& Coastal Management 128:10-17

de Jesus Piñon-Colin T, Rodriguez-Jimenez R, Pastrana-Corral MA, et al (2018) Microplastics on sandy beaches of the Baja California Peninsula, Mexico. Marine Pollution Bulletin 131:63-71

Dehghani, S., Moore, F. \& Akhbarizadeh, R (2017) Microplastic pollution in deposited urban dust, Tehran metropolis, Iran. Environmental Science \& Pollution Research 24, 20360-20371.

Dowarah K, Devipriya SP (2019) Microplastic prevalence in the beaches of Puducherry, India and its correlation with fishing and tourism/recreational activities. Marine Pollution Bulletin 148:123-133

Doyen, P., Hermabessiere, L., Dehaut, A. et al (2019) Occurrence and identification of microplastics in beach sediments from the Hauts-de-France region. Environmental Science \& Pollution Research 26, 2801028021.

Edo C, Tamayo-Belda M, Martínez-Campos S, et al (2019) Occurrence and identification of microplastics along a beach in the Biosphere Reserve of Lanzarote. Marine Pollution Bulletin 143:220-227 
Engler RE (2012) The complex interaction between marine debris and toxic chemicals in the ocean. Environmental Science \& Technology 46:12302-12315

Europe P (2015) An analysis of European plastics production, demand and waste data. Plastics-the facts

Facts PEP-T (2019) An analysis of European plastics production, demand and waste data

Frias J, Gago J, Otero V, Sobral P (2016) Microplastics in coastal sediments from Southern Portuguese shelf waters. Marine Environmental Research 114:24-30

Gao F, Li J, Hu J, et al (2020) Occurrence of microplastics carried on Ulva prolifera from the Yellow Sea, China. Case Studies in Chemical and Environmental Engineering 2:100054

Gopinath, K., Seshachalam, S., Neelavannan, K. et al (2020) Quantification of microplastic in Red Hills Lake of Chennai city, Tamil Nadu, India. Environmental Science \& Pollution Research 27, 33297-33306

Guo X, Wang J (2019) The chemical behaviors of microplastics in marine environment: A review. Marine Pollution Bulletin 142:1-14

Hengstmann E, Tamminga M, vom Bruch C, Fischer EK (2018) Microplastic in beach sediments of the Isle of Rügen (Baltic Sea)-Implementing a novel glass elutriation column. Marine Pollution Bulletin 126:263274

Hidalgo-Ruz V, Gutow L, Thompson RC, Thiel M (2012) Microplastics in the marine environment: a review of the methods used for identification and quantification. Environmental Science \& Technology 46:30603075

Hidalgo-Ruz V, Thiel M (2013) Distribution and abundance of small plastic debris on beaches in the SE Pacific (Chile): a study supported by a citizen science project. Marine Environmental Research 87:12-18

Ivar do SJ, Spengler Â, Costa MF (2009) Here, there and everywhere. Small plastic fragments and pellets on beaches of Fernando de Noronha (equatorial western Atlantic). Marine Pollution Bulletin 58:1236

Iwasaki S, Isobe A, Kako S, et al (2017) Fate of microplastics and mesoplastics carried by surface currents and wind waves: A numerical model approach in the Sea of Japan. Marine Pollution Bulletin 121:85-96

Jambeck JR, Geyer R, Wilcox C, et al (2015) Plastic waste inputs from land into the ocean. Science 347:768-771

Jayasiri HB, Purushothaman CS, Vennila A (2013) Quantitative analysis of plastic debris on recreational beaches in Mumbai, India. Marine Pollution Bulletin 77:107-112

Jiang Y, Yang F, Zhao Y, et al (2020a) WITHDRAWN: Abundance and characteristics of microplastics in the Bellingshausen Sea, Antarctica, are distinguished by the Southern Antarctic Circumpolar Current Front. Elsevier

Jiang Y, Yang F, Zhao Y, Wang J (2020b) Greenland Sea Gyre increases microplastic pollution in the surface waters of the Nordic Seas. Science of the Total Environment 712:136484

Jilan S (2004) Overview of the South China Sea circulation and its influence on the coastal physical oceanography outside the Pearl River Estuary. Continental Shelf Research 24:1745-1760

Karthik R, Robin RS, Purvaja R, et al (2018) Microplastics along the beaches of southeast coast of India. Science of the Total Environment 645:1388-1399

Kelly A, Lannuzel D, Rodemann T, et al (2020) Microplastic contamination in east Antarctic sea ice. Marine Pollution Bulletin 154:111130

Khatmullina L, Chubarenko I (2019) Transport of marine microplastic particles: why is it so difficult to predict? Anthropocene Coasts 2:293-305

Khatmullina L, Isachenko I (2017) Settling velocity of microplastic particles of regular shapes. Marine Pollution Bulletin 114:871-880

Khatmullina L, Isachenko I (2017) Settling velocity of microplastic particles of regular shapes. Marine Pollution Bulletin 114, 871-880

Kim I-S, Chae D-H, Kim S-K, et al (2015) Factors influencing the spatial variation of microplastics on high-tidal coastal beaches in Korea. Archives of Environmental Contamination and Toxicology 69:299-309 
Klangnurak, W., Chunniyom, S (2020) Screening for microplastics in marine fish of Thailand: the accumulation of microplastics in the gastrointestinal tract of different foraging preferences. Environmental Science \& Pollution Research 27, 27161-27168

Kukulka T, Proskurowski G, Morét-Ferguson S, Meyer D.W, Law K.L (2012) The effect of wind mixing on the vertical distribution of buoyant plastic debris. Geophysical Research Letters 39

Lattin GL, Moore CJ, Zellers AF, et al (2004) A comparison of neustonic plastic and zooplankton at different depths near the southern California shore. Marine Pollution Bulletin 49:291-294

Law KL, Thompson RC (2014) Microplastics in the seas. Science 345:144-145

Leslie HA, Brandsma SH, Van Velzen MJM, Vethaak AD (2017) Microplastics en route: Field measurements in the Dutch river delta and Amsterdam canals, wastewater treatment plants, North Sea sediments and biota. Environment International 101:133-142

Li J, Zhang H, Zhang K, et al (2018) Characterization, source, and retention of microplastic in sandy beaches and mangrove wetlands of the Qinzhou Bay, China. Marine Pollution Bulletin 136:401-406

Liu J, Liu N, Zhang Y, et al (2019) Evaluation of the non-use value of beach tourism resources: A case study of Qingdao coastal scenic area, China. Ocean \& Coastal Management 168:63-71

Liu X, Chiang K-P, Liu S-M, et al (2015) Influence of the Yellow Sea Warm Current on phytoplankton community in the central Yellow Sea. Deep Sea Research Part I: Oceanographic Research Papers 106:17-29

Lo H-S, Xu X, Wong C-Y, Cheung S-G (2018) Comparisons of microplastic pollution between mudflats and sandy beaches in Hong Kong. Environmental Pollution 236:208-217

Lots FA, Behrens P, Vijver MG, et al (2017) A large-scale investigation of microplastic contamination: abundance and characteristics of microplastics in European beach sediment. Marine Pollution Bulletin 123:219-226

Mai, Y., Peng, S., Lai, Z. et al (2021) Measurement, quantification, and potential risk of microplastics in the mainstream of the Pearl River (Xijiang River) and its estuary, Southern China. Environmental Science \& Pollution Research (2021)

Mako W (2006) China: governance, investment climate, and harmonious society: competitiveness enhancements for 120 cities in China. World Bank

Masiá P, Ardura A, Garcia-Vazquez E (2019) Microplastics in special protected areas for migratory birds in the Bay of Biscay. Marine Pollution Bulletin 146:993-1001

Mathalon A, Hill P (2014) Microplastic fibers in the intertidal ecosystem surrounding Halifax Harbor, Nova Scotia. Marine Pollution Bulletin 81:69-79

Monteiro R.C, do Sul J.A.I, Costa M.F (2018) Plastic pollution in islands of the Atlantic Ocean. Environmental Pollution 238, 103-110.

Muhammad Husin, M.J., Mazlan, N., Shalom, J. et al (2021) Evaluation of microplastics ingested by sea cucumber Stichopus horrens in Pulau Pangkor, Perak,Malaysia. Environmental Science \& Pollution Research https://doi.org/10.1007/s11356-021-15099-4

Naidoo T, Glassom D, Smit AJ (2015) Plastic pollution in five urban estuaries of KwaZulu-Natal, South Africa. Marine Pollution Bulletin 101:473-480

Naji A, Esmaili Z, Khan FR (2017) Plastic debris and microplastics along the beaches of the Strait of Hormuz, Persian Gulf. Marine Pollution Bulletin 114:1057-1062

Nan B, Su L, Kellar C, et al (2020) Identification of microplastics in surface water and Australian freshwater shrimp Paratya australiensis in Victoria, Australia. Environmental Pollution 259:113865

Nishikida K, Coates J (2003) Infrared and Raman analysis of polymers. PLASTICS ENGINEERING-NEW YORK- 68:201-340

Noda I, Dowrey AE, Haynes JL, Marcott C (2007) Group frequency assignments for major infrared bands observed in common synthetic polymers. In: Physical properties of polymers handbook. Springer, pp 395-406

Nor N.H.M, Obbard J.P (2014) Microplastics in Singapore's coastal mangrove ecosystems. Marine Pollution Bulletin 79, 278-283 
Nor NHM, Obbard JP (2014) Microplastics in Singapore's coastal mangrove ecosystems. Marine Pollution Bulletin 79:278-283

Ory NC, Sobral P, Ferreira JL, Thiel M (2017) Amberstripe scad Decapterus muroadsi (Carangidae) fish ingest blue microplastics resembling their copepod prey along the coast of Rapa Nui (Easter Island) in the South Pacific subtropical gyre. Science of the Total Environment 586:430-437

Pedrotti M.L, Petit S, Elineau A, Bruzaud S, Crebassa J C, Dumontet B, Martí E, Gorsky G, Cózar A (2016) Changes in the floating plastic pollution of the Mediterranean Sea in relation to the distance to land. PloS one $11, \mathrm{e} 0161581$

Pedrotti ML, Petit S, Elineau A, et al (2016) Changes in the floating plastic pollution of the Mediterranean Sea in relation to the distance to land. PloS one 11:e0161581

Pereao, O., Opeolu, B. \& Fatoki, O (2020) Microplastics in aquatic environment: characterization, ecotoxicological effect, implications for ecosystems and developments in South Africa. Environmental Science \& Pollution Research 27, 22271-22291

Pervez R, Wang Y, Mahmood Q, Jattak Z (2020) Stereomicroscopic and Fourier Transform Infrared (FTIR) Spectroscopic Characterization of the Abundance, Distribution and Composition of Microplastics in the Beaches of Qingdao, China. Analytical Letters 1-18

Qiu Q, Peng J, Yu X, et al (2015) Occurrence of microplastics in the coastal marine environment: first observation on sediment of China. Marine Pollution Bulletin 98:274-280

Rochman CM (2015) The complex mixture, fate and toxicity of chemicals associated with plastic debris in the marine environment. In: Marine anthropogenic litter. Springer, Cham, pp 117-140

Sana, S.S., Dogiparthi, L.K., Gangadhar, L. et al (2020) Effects of microplastics and nanoplastics on marine environment and human health. Environmental Science \& Pollution Research 27, 44743-44756

Sarijan, S., Azman, S., Said, M.I.M. et al (2021) Microplastics in freshwater ecosystems: a recent review of occurrence, analysis, potential impacts, and research needs. Environmental Science \& Pollution Research 28, 1341-1356

Sharma, S., Chatterjee, S (2017) Microplastic pollution, a threat to marine ecosystem and human health: a short review. Environmental Science \& Pollution Research 24, 21530-21547

Shen, M., Zeng, Z., Wen, X. et al (2021) Presence of microplastics in drinking water from freshwater sources: the investigation in Changsha, China. Environmental Science \& Pollution Research. https://doi.org/10.1007/s11356-021-13769-X

Simon-Sánchez L, Grelaud M, Garcia-Orellana J, Ziveri P (2019) River Deltas as hotspots of microplastic accumulation: The case study of the Ebro River (NW Mediterranean). Science of The Total Environment 687:1186-1196

Sun X, Li Q, Shi Y, et al (2019) Characteristics and retention of microplastics in the digestive tracts of fish from the Yellow Sea. Environmental Pollution 249:878-885

Sun X, Liang J, Zhu M, et al (2018) Microplastics in seawater and zooplankton from the Yellow Sea. Environmental Pollution 242:585-595

Tamminga M, Stoewer S-C, Fischer EK (2019) On the representativeness of pump water samples versus manta sampling in microplastic analysis. Environmental Pollution 254:112970

Tavşanoğlu, Ü.N., Başaran Kankılıç, G., Akca, G. et al (2020) Microplastics in a dam lake in Turkey: type, mesh size effect, and bacterial biofilm communities. Environmental Science \& Pollution Research 27, 4568845698

Ter Halle A, Ladirat L, Gendre X, et al (2016) Understanding the fragmentation pattern of marine plastic debris. Environmental Science \& Technology 50:5668-5675

Thompson RC, Olsen Y, Mitchell RP, et al (2004) Lost at sea: where is all the plastic? Science (Washington) $304: 838$

Tiwari M, Rathod TD, Ajmal PY, et al (2019) Distribution and characterization of microplastics in beach sand from three different Indian coastal environments. Marine Pollution Bulletin 140:262-273 
Veerasingam S, Mugilarasan M, Venkatachalapathy R, Vethamony P (2016) Influence of 2015 flood on the distribution and occurrence of microplastic pellets along the Chennai coast, India. Marine Pollution Bulletin 109:196-204

Verleye GA, Roeges NP, De Moor MO (2001) Easy identification of plastics and rubbers. iSmithers Rapra Publishing

Vianello A, Boldrin A, Guerriero P, et al (2013) Microplastic particles in sediments of Lagoon of Venice, Italy: First observations on occurrence, spatial patterns and identification. Estuarine, Coastal and Shelf Science 130:54-61

Wang, T., Li, B. \& Wang, D (2021) The abundance and characteristics of microplastics in commonly consumed shellfish in the Jiangsu coastal region of China. Environmental Science \& Pollution Research. https://doi.org/10.1007/s11356-021-14977-1

Wu P, Tang Y, Dang M, et al (2020) Spatial-temporal distribution of microplastics in surface water and sediments of Maozhou River within Guangdong-Hong Kong-Macao Greater Bay Area. Science of the Total Environment 717:135187

Wu, X., Zhong, C., Wang, T. et al (2021) Occurrence and distribution of microplastics on recreational beaches of Haichow Bay, China. Environmental Science \& Pollution Research 28, 6132-6145

Xiong X, Chen X, Zhang K, et al (2018) Microplastics in the intestinal tracts of East Asian finless porpoises (Neophocaena asiaeorientalis sunameri) from Yellow Sea and Bohai Sea of China. Marine Pollution Bulletin 136:55-60

Xu P, Peng G, Su L, et al (2018) Microplastic risk assessment in surface waters: A case study in the Changjiang Estuary, China. Marine Pollution Bulletin 133:647-654

Xu, Q., Deng, T., LeBlanc, G.A. et al (2020) An effective method for evaluation of microplastic contaminant in gastropod from Taihu Lake, China. Environmental Science \& Pollution Research 27, 22878-22887

Yuan W, Liu X, Wang W, et al (2019) Microplastic abundance, distribution and composition in water, sediments, and wild fish from Poyang Lake, China. Ecotoxicology and Environmental Safety 170:180-187

Yuan, F., Zhao, H., Sun, H. et al (2021) Abundance, morphology, and removal efficiency of microplastics in two wastewater treatment plants in Nanjing, China. Environmental Science \& Pollution Research 28, 93279337

Zhang C, Zhou H, Cui Y, et al (2019) Microplastics in offshore sediment in the yellow Sea and east China Sea, China. Environmental Pollution 244:827-833

Zhang D, Cui Y, Zhou H, et al (2020) Microplastic pollution in water, sediment, and fish from artificial reefs around the Ma'an Archipelago, Shengsi, China. Science of the Total Environment 703:134768

Zhang K, Shi H, Peng J, et al (2018) Microplastic pollution in China's inland water systems: a review of findings, methods, characteristics, effects, and management. Science of the Total Environment 630:1641-1653

Zhao J, Ran W, Teng J, et al (2018) Microplastic pollution in sediments from the Bohai Sea and the Yellow Sea, China. Science of the Total Environment 640:637-645

Zhao Y, Sun X, Li Q, et al (2019) Data on microplastics in the digestive tracts of 19 fish species from the Yellow Sea, China. Data in brief 25:103989

Zhou Q, Zhang H, Fu C, et al (2018) The distribution and morphology of microplastics in coastal soils adjacent to the Bohai Sea and the Yellow Sea. Geoderma 322:201-208

Zhu J, Zhang Q, Li Y, et al (2019) Microplastic pollution in the Maowei Sea, a typical mariculture bay of China. Science of the Total Environment 658:62-68 


\section{Supplementary Files}

This is a list of supplementary files associated with this preprint. Click to download.

- SupplimantryData.docx 